\title{
Thoughts on Interlibrary Loan
}

$\mathrm{A}_{\text {terlibrary Loan Costs" }}^{\text {LAN HolsKe's paper "On Meeting In- }}$ fact that the subject is not so simple as would appear at first sight and that it is inextricably involved with the book-buying capacity of educational institutions and with the problem of regional cooperation among libraries. But his final paragraph leans heavily toward the individual professor in whose behalf loans are generally made:

Meanwhile, the borrowers of books on interlibrary loan should be relieved of money penalties whenever possible. The free circulation of books is today more than ever an important expression of American civilization, and it should be American policy everywhere and at all times. ${ }^{2}$

However, it appears to the writer, who has had a fair share of being both a borrower and a lender, that this cannot be the last word on the subject. Practical experience with the problem soon dispels rosy illusions and emphasizes the fact that only in Utopia would such a policy be possible.

Some professors believe that they should be allowed unlimited interlibrary loan, and there are few who do not object when asked to defray the cost. Incidentally, by "cost" is meant the actual mail or express charges, not the postage on any letters that may have to be written negotiating the loan before it is consummated. There is never any question, nor should there be, of paying any member of the library staff, even though the interlibrary loan request may have taken considerable time of a library

${ }^{1}$ Holske, Alan. "On Meeting Interlibrary Loan Costs." College and Research Libraries 7:74-77, January 1946.

Ibid., p. 77 . assistant for verification, checking bibliographical data, locating the material in a library, and correspondence. This is mentioned only to emphasize that the professor is getting a great deal of service for his money even if he does pay the postage. And yet, cases have been known when a professor scanned the package in which his books arrived and objected if his bill exceeded the value of the stamps on the wrapper, quite disregarding the insurance.

It is true that the chief reason on the part of librarians for advocating payment of postage by the professor is that this does tend to "abate a nuisance" and to prevent "the abuse of trivial requests." It may be argued that the library should be able to afford postage on the relatively small number of books borrowed in any given year. The answer is that the only reason the number remains relatively small is that the loan costs the borrowing individual something. The same reason can be given for the fact that so few requests are "trivial." The best proof of this statement is actual experience.

The writer once worked in a library where there was no charge for interlibrary loan. The result was appalling. On any and every excuse, students and faculty demanded that books be borrowed for them on interlibrary loan. As an example of triviality, it might be mentioned that even if the library possessed a certain book, a reader would ask for it on interlibrary loan if it happened to be out when he called for it. Needless to say, this system finally broke down on account of its inevitable abuse.

As to the lengths to which one individual 
will go unless checked by the economic motive, there is the case of Professor Smith. He happened to meet the librarian one day, mentioned that he was preparing an article, and announced that he needed some books on interlibrary loan. He was told to bring in a list of wanted titles. Although he brought in a list of thirty-five items, discussion revealed that he intended to request over three hundred before he was through. In the end, the only effective argument that led him to cut down his request to reasonable proportions was the economic one. $\mathrm{He}$ was convinced that the cost-to him-of sending for so many books and returning them would be prohibitive. Had the library been paying the postage, he undoubtedly would have insisted on his "rights."

The first impression that one gathers from an incident such as this is its futility. If a professor, who is generally a specialist in a certain field, intends to write a short article on some subject within that field, why should it be necessary for him to consult three hundred books by other authors as a preliminary step? If he wishes to make excerpts, or has to look up a few minor points, dates, facts, or figures, he might far better go to the library where the books are to be found. And, it may be repeated, it is only the cost to himself that teaches him any restraint.

\section{Reasons for Borrowing}

Some questionable statements have been made about the reasons for interlibrary borrowing by professors. Their work is frequently referred to as "research projects," "enlarging the bounds of knowledge," and by similar expressions. Yet, in actual fact, what is the purpose of a professor's study which requires the aid of interlibrary loan? It would seem to fall into two main categories: first, the man is working on his thesis, and second, on some article or book.
Clearly much of both types of work may be primarily for himself and his own advancement. In brief, sometimes it is the professor and not the college that benefits by his outside work, and in such cases the beneficiary should pay the necessary cost.

There is another reason, too, why a librarian should try to exert control over the book borrowing of the professors. It should constantly be borne in mind that the lending of books by a library is a favor and a courtesy. It is not and should not be considered a right on the part of the borrower. The idea is well expressed by Winchell, who writes:

Thus the practice of the loaning of books by one library to another has grown from an occasional favor to a more or less organized system. This, however, should not release the borrowing library from a sense of appreciation and a realization that to request a loan is still to ask a favor. ${ }^{3}$

But if too many and too trivial requests are made, this courtesy may become a burden which will eventually be resented as an imposition. In the case of the professor who wanted three hundred books for one article, this aspect was a factor in the case. The library from which he wanted the books was one which had in the past done the borrowing library many favors. Common sense required restraint in requesting material. And, of course, the excessive demands of the professor in question would have been attributed, not to him individually, but to the borrowing library.

There is still another aspect of the matter which has not been discussed in the literature on interlibrary loan but which seems worthy of mention.

Assume that Professor Jones is on the faculty of College A, but is studying for his Ph.D. at University B. Perhaps only his

\footnotetext{
${ }^{3}$ Winchell, Constance. Locating Books for Interlibrary Loan. New York City, H. W. Wilson, 1930, p. 14 .
} 
thesis is holding him up, but that requires the use of books not found in the library of College A, which is an undergraduate institution. Within convenient borrowing distance is University C. Professor Jones is not enrolled there as a student, he is not paying that university any tuition money, he is not an alumnus of it. The only claim he can have to the books of University C is by the courtesy of interlibrary loan. And for the use of its books by Professor Jones, and the work of its staff in taking care of his wants, University $C$ receives not one cent. Does this not pose some sort of economic or ethical question?

\section{Institutions Often at Fault}

Now, it may be objected that excessive use of interlibrary loan service is not the fault of the professor. It is perfectly true that many institutions insist on constant publication by their professors as the price of promotion or even of tenure. Such a policy gives rise to the endless production of books and articles. And to make this production possible for the professor so situated as to be out of touch with a large library, the custom of interlibrary loan must bear a greatly increased burden.

Let us admit that it is the duty of the librarian to do all in his power to prevent abuses of interlibrary loan and to keep the practice within bounds. One of the best ways to bring this about is to enforce the code formulated in 1917 by the Committee on Coordination of the American Library Association. It deals with such matters as the purpose of interlibrary loans, the material which is legitimate for borrowing and that which is not, for what individuals loans should be requested, and the types of libraries which should be solicited. It is not necessary to quote this somewhat lengthy code in full. Briefly, it may be said to consist of applied common sense.
In almost every case it is the lending library that can do the most effective work in enforcing this code. For example, let us say that our old friend Professor Smith asks the librarian to borrow for him a certain item that is clearly illegal under the A.L.A. code. The librarian carefully explains that fact and indicates his unwillingness to ask for the item. Invariably Professor Smith's answer will be, "But there's no harm in trying. They can't do more than say 'No.', $\mathrm{He}$ may even reinforce his argument with an insinuation that the librarian is too lazy to try or is being purposely unobliging.

The librarian writes for the item, and, contrary to expectations, it arrives. Professor Smith receives it with undisguised triumph, his words or manner clearly expressing the idea, "I told you so! You see, I got away with it. Luckily I did not take you too seriously."

But suppose the library thus solicited had written back regretting its inability to send the material because to do so would be contrary to the A.L.A. code. Would Professor Smith have tried the same approach again?

\section{Business-Like Methods Necessary}

Although it may seem unnecessary to mention such an obvious fact, there is great need for both borrowing and lending libraries to employ the strictest business-like methods in handling these transactions. For example, by its name, interlibrary loan should be a transaction between two libraries, never between a library and an individual. Of course, such a loan is always requested on behalf of some individual, but such is not and should not be the theory behind it. It is the borrowing library which makes the request and to which the book is sent. To be sure, the lending library has the right to impose certain conditions, such as that the material must not be taken out of the building of the borrowing library. 
But in every case the loan is made to a library and it is the borrowing library that is responsible for the safety of the material.

Of course, the objection may be made that nothing so far expressed has considered the problem from the borrower's point of view. Assuming that a professor needs books not to be found in his own library, how can he obtain them without imposing an impossible burden on himself and also on some other library?

In the case of any institution where constant publication on the part of faculty members is compulsory - that is, necessary for tenure-the administration should set aside a fund to defray the expense of interlibrary loan. Whether this should be part of the library fund or that of the departments, and how it should be apportioned, are matters of individual policy.

When the work in question is solely for the professor's own benefit, it seems not only fair but advisable that he pay the cost. In the case of work for a degree, the books should always be requested first from the university where he is enrolled, and no other library should be appealed to until that one has been tried.

\section{Regional Agreements}

For the rest, it may well be that regional agreements among the libraries of a given locality may be the answer. These agreements might well cover such matters as avoidance of duplication of purchase and union catalogs, as well as interlibrary loan. An example of such an arrangement is that between the libraries of Duke University and the University of North Carolina. These libraries not only have union catalogs of each others' collections with mutual lending, but there is a truck service between the two to hasten deliveries. Some such understanding is now under consideration for the college libraries of South Carolina, though at present it has not progressed beyond the nebulous stage of discussion and conference.

\section{Education for Librarianship}

\section{(Continued from page I3I)}

the university concerned. If the "deans within deans" who manage our graduate schools are not willing to honor such a program by a degree, can we not accept a statement of work done and take the lead in selecting the first-class article that we want, on its merits and not for its tag?

It seems to me that we now have a very helpful body of literature before us on education for librarianship. To this, Mr. Danton's interesting pamphlet is an excellent guide. Let us hope that discussion to follow, and future publications as well, will keep open the question of in-service training, so that it may be thoroughly tried. We already have available to us fruitful suggestions for a greater division of labor in libraries and for better use of clerical help derived from high school and junior colleges. These and other devices for reducing costs will be very necessary if we are to provide adequate salaries for much more highly trained people. Then, if we permit all of this thought and writing and talking to bog down without good results, we shall doubtless continue to fail to bring our libraries into proper focus at the center of liberal education provided in our institutions; and we shall at least partially justify the all too common misconception of our function that classes us as housekeepers of books rather than with educators who teach not in a classroom but through the conduct of a library. 